\author{
Military Technical College \\ Kobry Elkobbah, Cairo, \\ Egypt.
}

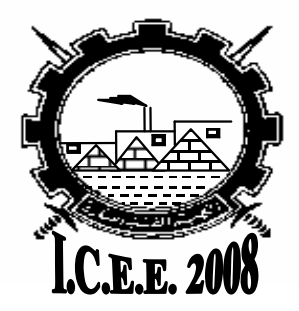

$4^{\text {th }}$ International Conference On Chemical \& Environmental Engineering 27-29 May 2008

\title{
PERFORMANCE AND STABILITY OF MODERN GUN PROPELLANTS
}

\author{
S. A. Shoukry*, M. M. Ismail ${ }^{\star *}$ and A. Abd Elgwad ${ }^{* *}$
}

\begin{abstract}
Different RDX based gun propellant compositions were prepared using slurry technique. Ballistic performance of the compositions was evaluated on the basis of closed vessel test. Heat of combustion was measured using a calorimetric bomb. Sensitivity, some thermal characteristics and thermal stability of the compositions were investigated. The obtained results reveal that gun propellant compositions based on approximately 58 percent RDX could provide relatively high level of powder force, acceptable maximum pressure and good stability.
\end{abstract}

\section{KEY WORDS}

RDX based gun propellants, Vivacity, Stability and Performance.

\footnotetext{
${ }^{*}$ Research Design and Technology Development Center of Military Production.

** Egyptian Armed Forces
} 


\section{INTRODUCTION}

Nitramine based gun propellants have been suggested to be utilized rather than double base propellants in certain gun propulsion applications (tank gun ammunition). Nitramines utilized are primarily RDX, which selected because it offers many advantages for advanced gun propulsion such as improvement in performance (high energy content), better thermal stability and low cost [1]. XM39 [RDX 76\%, cellulose acetate butyrate (CAB) $12 \%$, acetyl triethyl citrate $7.6 \%$, NC (12.6\%) $4 \%$ and ethyl centralite $0.4 \%$ ] composition was developed in the beginning of 1980 . Acetyl TriEthyl Citrate (ATEC) was the plasticizer of original XM39 LOVA gun propellant formulation. ATEC is an excellent plasticizer and imparts desirable vulnerability properties. However, it is a very inert Plasticizer so that XM39 has low impetus. Since the development of the original of XM39 formulation, there has been an emphasis to increase the impetus level of LOVA propellant with minimal or no effect on LOVA vulnerability properties [2].

LOVA gun propellant with GAP (Glyciyl Azide Polymer) binder instead of inert binder (CAB) offers better burning characteristics. $87 \%$ RDX and 13\% GAP gives impetus more than $200 \mathrm{~J} / \mathrm{g}$ higher compared with the conventional JA-2 propellant [3]. A new propellant was designed with CL-20 as main energetic component has powder force $1253 \mathrm{~J} / \mathrm{g}[4]$.

In this paper performance and stability of modern gun propellants were studied. Different gun propellant compositions based on RDX, Nitrocellulose and inert binder were prepared using slurry technique. Ballistic performance of the compositions was evaluated on the basis of closed vessel test. Heat energy was measured using a calorimetric bomb. Sensitivity, some thermal characteristics and stability of the compositions were determined.

\section{EXPERIMENTAL WORK}

Eight compositions of modern gun propellant based on RDX, polyisobutylene and nitrocellulose $(12.0 \% \mathrm{~N})$ were prepared using slurry technique $[5,6]$. The calculated amounts of polyisobutylene, nitrocellulose and RDX were accurately weighed after careful drying. Polyisobutylene was dissolved in trichloroethylene with suitable heating

(water bath at $80^{\circ} \mathrm{C}$ ) and mechanical stirring to ensure complete dissolution till a lacquer was produced. A slurry of RDX in six times weight distilled water was added in small portions to the lacquer in a glass reactor provided with mechanical stirrer and in a water bath at $90{ }^{\circ} \mathrm{C}$. Nitrocellulose solution [nitrocellulose in ten times weight of ethyl acetate and centralite I (CI), diphenylamine (DPA)] was added in small portions to the

glass reactor. Stirring was continued for 30 minutes after complete addition of nitrocellulose solution to ensure good mixing. After complete addition of RDX slurry and nitrocellulose solution temperature was increased to $95^{\circ} \mathrm{C}$ with stirring to evaporate the solvent. The mixture was then cooled, filtered and washed several times with distilled water. The obtained beads were dried at $60^{\circ} \mathrm{C}$ and then pressed to the required shape for testing. The compositions of the prepared modern gun propellants are listed in Table 
Table 1. Composition of the prepared RDX based gun propellants

\begin{tabular}{|c|c|c|c|c||c|c|c|c|}
\hline Sample No. & S1 & S2 & S3 & S4 & S5 & S6 & S7 & S8 \\
\hline Parameter & 65 & 60 & 55 & 50 & 56 & 58 & 60 & 62 \\
\hline RDX (wt \%) & 10 & 10 & 10 & 10 & 12 & 10 & 8 & 6 \\
\hline Polyisobutylene (wt \%) & 25 & 30 & 35 & 40 & 30 & 30 & 30 & 30 \\
\hline Nitrocellulose (wt \%) & - & - & - & - & 2 & 2 & 2 & 2 \\
\hline DOZ (wt \%) & - & &
\end{tabular}

\subsection{Sensitivity To Different Initial Impulse}

\section{(a) Sensitivity to Impact}

IKA Maschinebou apparatus was used to perform this test [7]. For the prepared formulations based on RDX, NC and Polyisobutylene, the values of upper limit sensitivity to impact (minimum height of falling hammer at which $100 \%$ explosions occur out of 6 repeated and successive trials) were determined.

\section{(b) Sensitivity to Friction}

Chilworth BAM friction apparatus was used to perform this test [8]. The sensitivity to friction for all the prepared gun propellants samples based on RDX, polyisobutylene and NC was determined using the standard technique. The applied force was increased gradually up to the maximum $(360 \mathrm{~N})$.

\section{(c) Sensitivity to Thermal stimuli}

Deflagration apparatus with heating rate $5 \mathrm{oC} / \mathrm{min}$ was used to perform this test [9]. Sensitivity of the prepared gun propellants formulations to thermal stimuli was assessed by determining the deflagration temperature.

\section{(d) Differential Thermal Analysis (DTA)}

Perkin Elmer DTA-7 apparatus was used to perform this test [10]. DTA thermograms were recorded in an inert atmosphere $\left(\mathrm{N}_{2}\right.$ gas) using $10 \mathrm{mg}$ of the selected samples in alumina crucibles at a heating rate of $10^{\circ} \mathrm{C} / \mathrm{min}$.

\subsection{Performance Of The Prepared Formulations}

\section{(a) Heat of Combustion}

Model 6200 Isoperibol PARR Bomb Calorimeter apparatus was used to perform this test [11]. For the prepared gun propellant formulations based on RDX and polyisobutylene and $\mathrm{NC}$, the calorific values (heat of combustion) were determined at 1 atm.

\section{(b) The ballistic bomb}

In $100 \mathrm{~cm}^{3}$ ballistic bomb, $15 \mathrm{~g}$ of the selected composition (S6) and $15 \mathrm{~g}$ reference sample (Triple base propellant) were burned and the maximum pressure and relative vivacity are determined in addition dynamic vivacity is measured. 


\subsection{Stability Of The Prepared Formulations}

To study the stability of modern gun propellants, four compositions were prepared by changing the type and content of stabilizer. Thermal stabilities of the compositions were determined using Bergmann Junk Test by heating $5 \mathrm{~g}$ samples (after drying at $50-60{ }^{\circ} \mathrm{C}$ for $1-2 \mathrm{hr}$ ) at $120{ }^{\circ} \mathrm{C}$ for $5 \mathrm{hr}$ and the total gaseous volume of nitrogen oxides was measured titrimetrically [12].

\section{RESULTS AND DISCUSSIONS}

\subsection{Sensitivity to Mechanical Simuli}

The obtained values from the impact test are given in Table (2). It is obvious that the sensitivity of the prepared formulations to impact is generally decreased by increasing the binder content as illustrated in Figure (1).

The low sensitivity to impact found for formulations based on polyisobutylene binder may be attributed to the fact that the coating effect on the RDX crystals of polyisobutylene binder will decrease the impact sensitivity.

Table 2. Values of upper limit of sensitivity to impact

\begin{tabular}{|l|c|c|}
\hline \multicolumn{1}{|c|}{ Composition (wt \%) } & $\begin{array}{c}\text { Impact energy } \\
\text { (Joule) }\end{array}$ & $\begin{array}{c}\text { Literature } \\
\text { values } \\
\text { (Joule) }\end{array}$ \\
\hline RDX 50, polyisobutylene 10, NC 40 & 9.00 & \\
RDX 55, polyisobutylene 10, NC 35 & 8.82 & Nitramine \\
RDX 60, polyisobutylene 10, NC 30 & 8.40 & gun \\
RDX 65, polyisobutylene 10, NC 25 & 7.84 & have average \\
RDX 62, polyisobutylene 6, NC 30, DOZ 2 & 9.60 & value (8.25- \\
RDX 60, polyisobutylene 8, NC 30, DOZ 2 & 9.80 & $9.8)$, [1]. \\
RDX 58, polyisobutylene 10, NC 30, DOZ 2 & 9.85 & \\
RDX 56, polyisobutylene 12, NC 30, DOZ 2 & 10.02 & \\
\hline
\end{tabular}




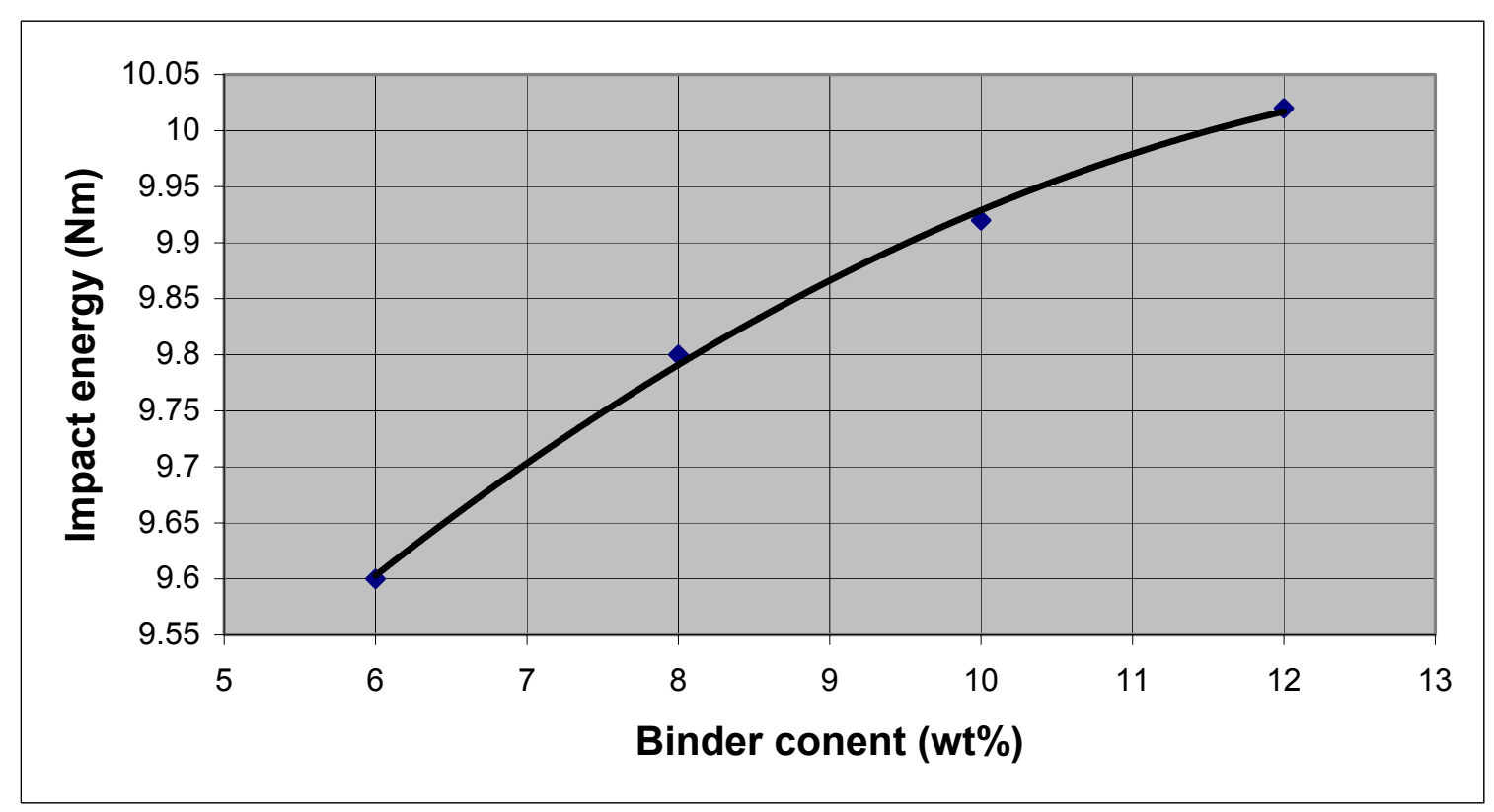

Fig.1. Dependence of sensitivity to impact (upper limit) on binder content

In determining the sensitivity to friction for all the prepared formulations, no indication of initiation was noticed even when applying the maximum force $(360 \mathrm{~N})$ of the test apparatus.

These results can be attributed to the satisfactory coating effect of the used binder to the RDX crystals by a thin layer. This low friction sensitivity enables us to use these formulations in severe conditions during production and handling.

\subsection{Thrermal Characteristics}

Deflagration temperature was measured and the experimental results are listed in Table (3) and illustrated in Figures (2). From Table (3), it is obvious that no significant change in deflagration temperature was noticed.

From Table (3), it is clear that the sensitivity of the prepared gun propellants to heat is generally increase by increasing the binder content as illustrated in Figure (2). This can be attributed to the fact that the coating of RDX with polyisobutylene acts as heat sensitizing medium (softening temperature is less than $125^{\circ} \mathrm{C}$ ). 
Table 3. Deflagration temperature of the prepared samples

\begin{tabular}{|l|c|c|}
\hline \multicolumn{1}{|c|}{ Composition (wt\%) } & $\begin{array}{c}\text { Deflagration } \\
\text { temperature } \\
\left({ }^{\circ} \mathbf{C}\right)\end{array}$ & $\begin{array}{c}\text { Literature } \\
\text { values }\left({ }^{\circ} \mathbf{C} \text { ) }\right.\end{array}$ \\
\hline RDX 50, polyisobutylene 10, NC 40 & 190 & \\
RDX 55, polyisobutylene 10, NC 35 & 193 & \\
RDX 60, polyisobutylene 10, NC 30 & 194 & Nitramine gun \\
RDX 65, polyisobutylene 10, NC 25 & 195 & propellants \\
\cline { 1 - 2 } RDX 62, polyisobutylene 6, NC 30, DOZ 2 & 197 & value average \\
RDX 60, polyisobutylene 8, NC 30, DOZ 2 & 196 & \\
RDX 58, polyisobutylene 10, NC 30, DOZ 2 & 194 & \\
RDX 56, polyisobutylene 12, NC 30, DOZ 2 & 192 & \\
\hline
\end{tabular}

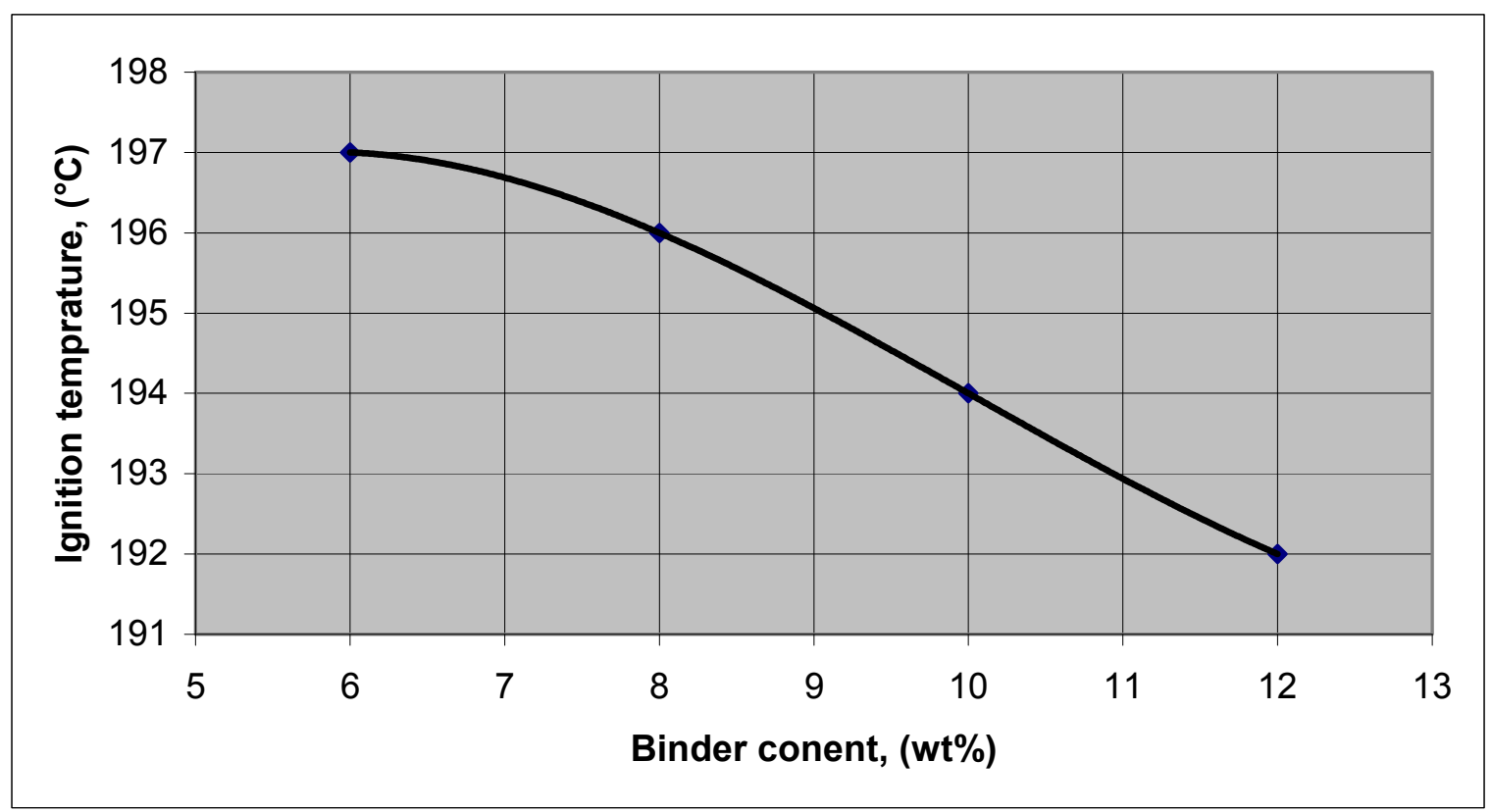

Fig.2. Dependence of deflagration temperature on binder content

DTA thermograms of the two compositons containing (RDX 55\%, polyisobutylene $10 \%$, NC $35 \%$ ) and (RDX\% 58, polyisobutylene 10\%, NC 30\%, DOZ $2 \%$ ) show uniformity and single mass decomposition, as only one exothermic was recorded.

The regular increase in the decomposition temperature is attributable to successively increased solid loading of RDX within the NC matrix.

For compositions containing (RDX 60\%, polyisobutylene 10\%, NC 30\%) and (RDX $60 \%$, polyisobutylene $8 \%$, NC $30 \%$, DOZ $2 \%$ ), respectivily, two exotherms have been recorded. The first exotherm at $180^{\circ} \mathrm{C}$ for the former and at $185^{\circ} \mathrm{C}$ for the latter indicate decomposition of propellant mass formed with the maximum loadable RDX within the NC matrix, whereas the second exotherm at $220{ }^{\circ} \mathrm{C}$ for the former and at 
$225^{\circ} \mathrm{C}$ for the latter, for both compositions indicates decomposition of surplus RDX. This observation indicates nonsuitability of these two compositions for gun propellant.

Table 4. Thermal characteristics data of selected compositions

\begin{tabular}{|c|c|c|}
\hline Composition (wt \%) & $\begin{array}{c}\text { DTA } \\
\text { decomposition } \\
\text { range }\end{array}$ & DTA thermogram \\
\hline $\begin{array}{c}\text { (a) RDX 60, polyisobutylene } \\
\text { 10, NC 30 }\end{array}$ & $180-217$ & $\begin{array}{c}\text { Two exotherms (one } \\
\text { sharp\& one weak) }\end{array}$ \\
\hline $\begin{array}{c}\text { (b) RDX 55, polyisobutylene } \\
\text { 10, NC 35 }\end{array}$ & $175-216$ & One exotherm (sharp) \\
\hline $\begin{array}{c}\text { (c) RDX 58, polyisobutylene } \\
\text { 10, NC 30, DOZ 2 }\end{array}$ & $167-208$ & $\begin{array}{c}\text { One exotherm } \\
\text { (sharp) }\end{array}$ \\
\hline $\begin{array}{c}\text { (d) RDX 60, polyisobutylene } \\
\text { 8, NC 30, DOZ 2 }\end{array}$ & $178-243$ & $\begin{array}{c}\text { Two exotherms (one } \\
\text { sharp\& one weak) }\end{array}$ \\
\hline
\end{tabular}

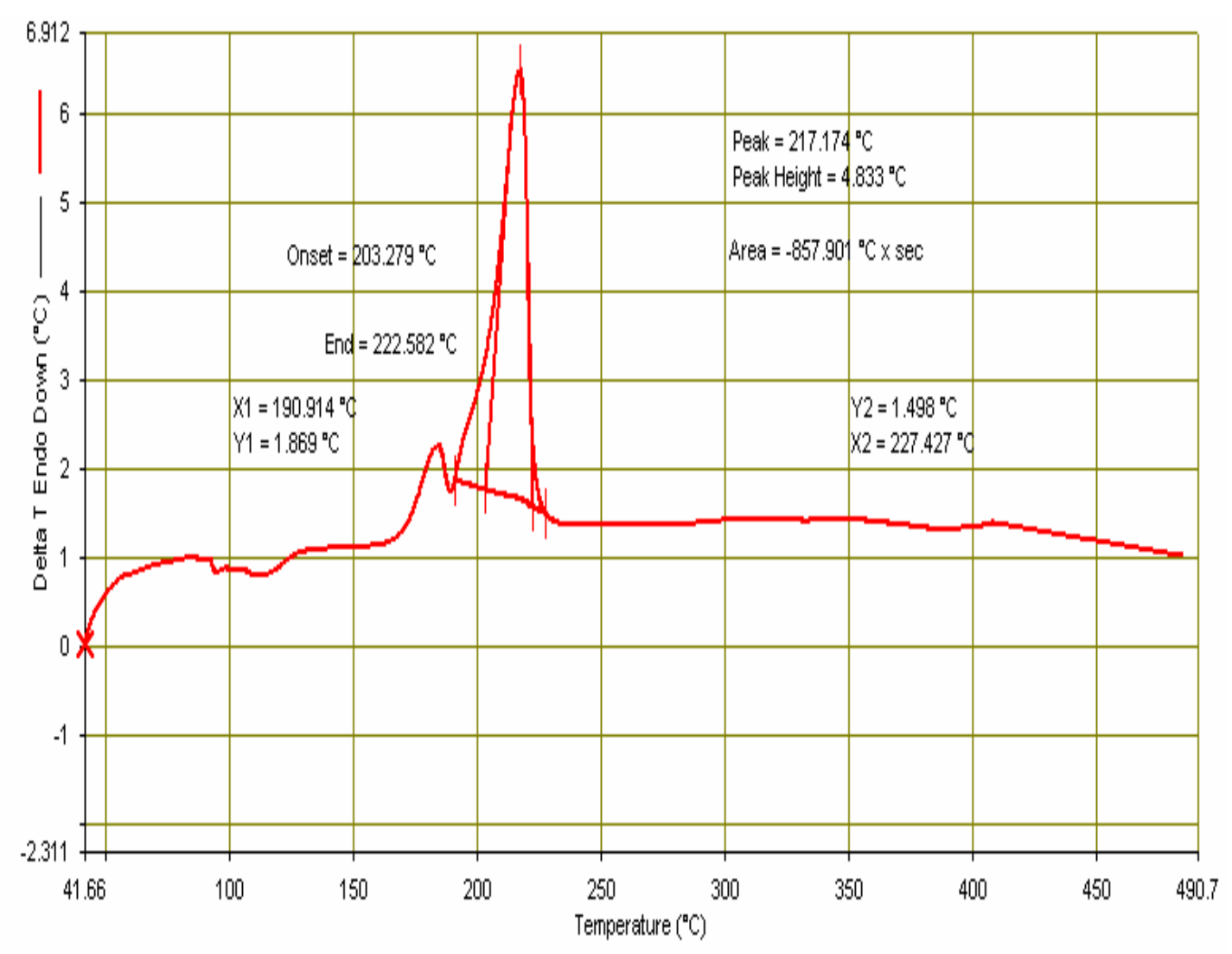

Fig. (3.a). RDX 60, polyisobutylene 10, NC 30 


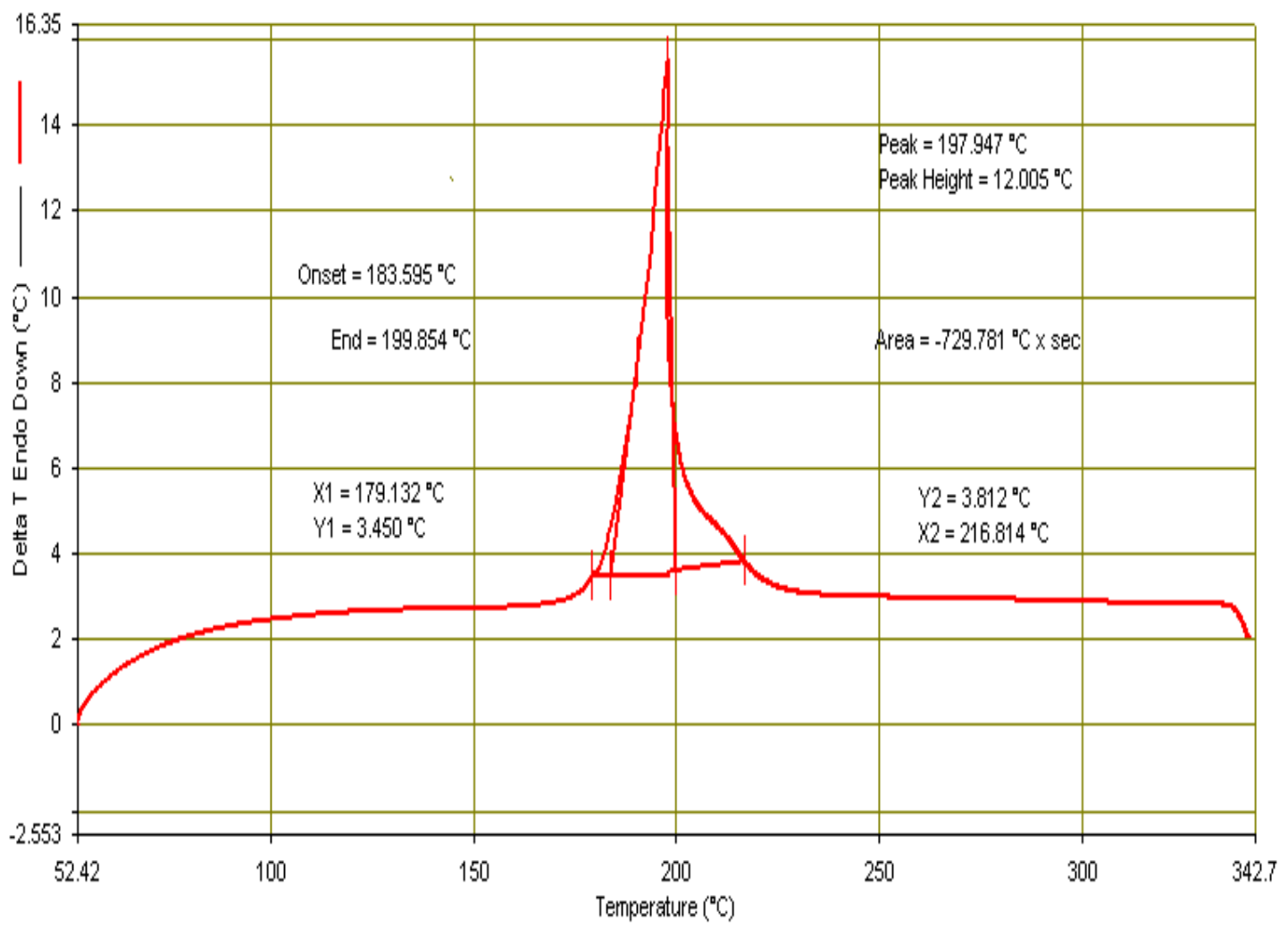

Fig. (3.b). RDX 55, polyisobutylene 10, NC 35

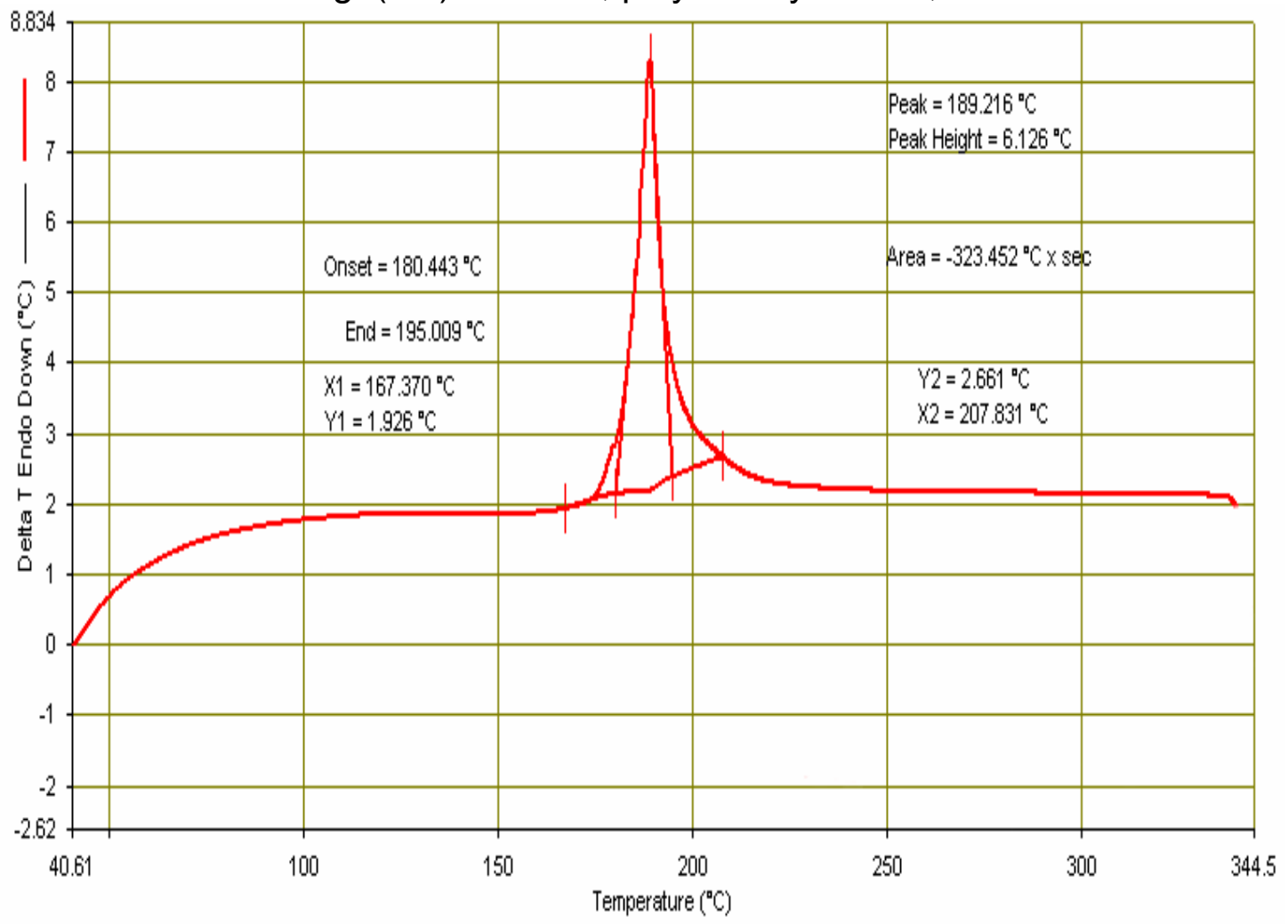

Fig. (3.c). RDX 58, polyisobutylene 10, NC 30, DOZ 2 


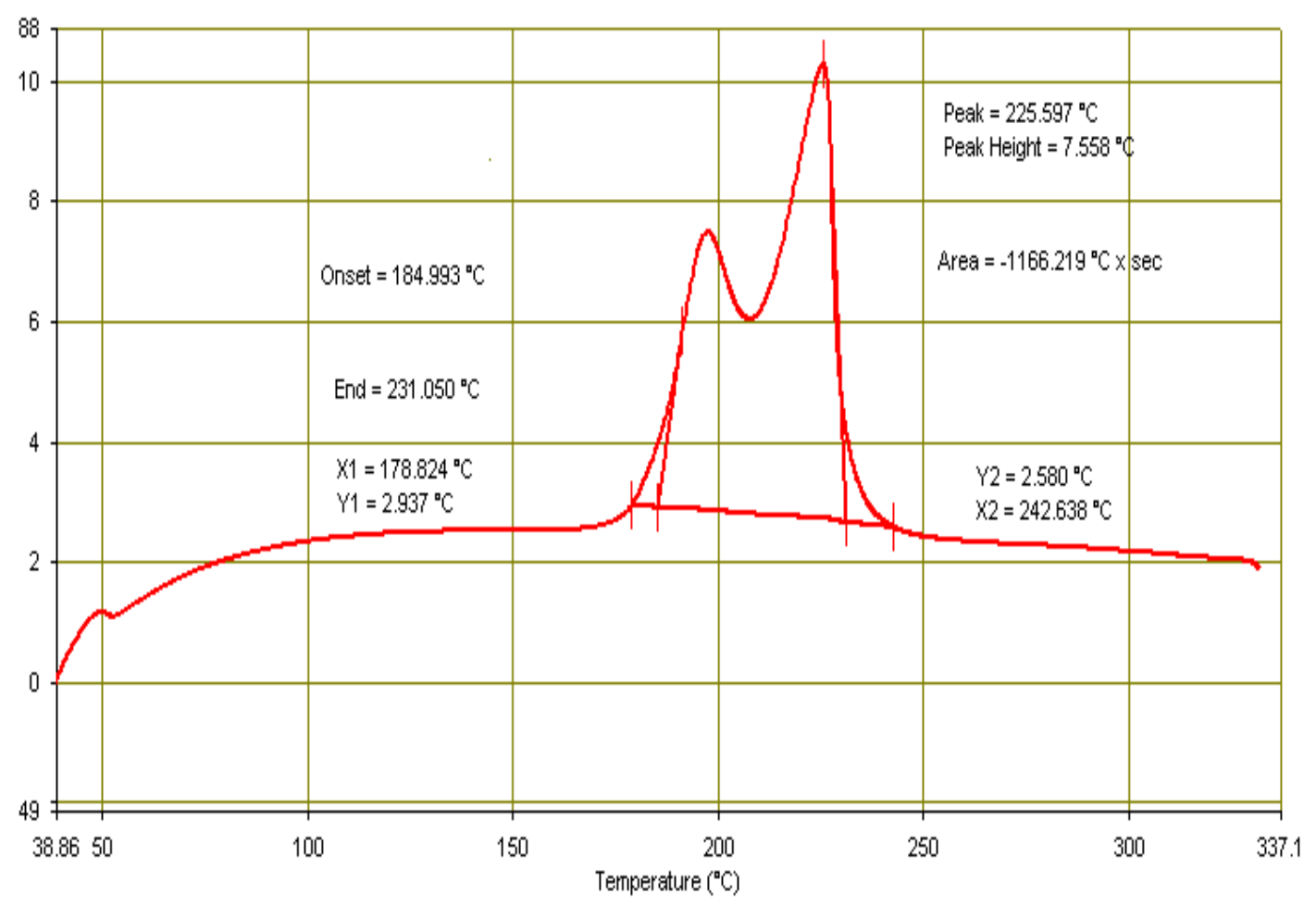

Fig. (3.d). RDX 60, polyisobutylene 8, NC 30, DOZ 2

Fig.3. DTA curves of the prepared formulations

\section{a. PERFORMANCE OF THE COMPOSITIONS}

The calorific values (heat of combustion) were determined at $1 \mathrm{~atm}$ and The results given in cal/g, are listed in Table (5) and illustrated in Figures (4).

Table 5. Combustion heat of the prepared formulations

\begin{tabular}{|c|c|c|}
\hline Composition (wt \%) & $\begin{array}{c}\text { Heat of } \\
\text { combustion } \\
\text { (cal/g) }\end{array}$ & $\begin{array}{c}\text { Literature values } \\
\text { (cal/g) }\end{array}$ \\
\hline RDX 50, polyisobutylene 10, NC 40 & 1027 & \\
RDX 55, polyisobutylene 10, NC 35 & 1046 & \\
RDX 60, polyisobutylene 10, NC 30 & 1090 & Nitramine gun \\
RDX 65, polyisobutylene 10, NC 25 & 1131 & propellants have \\
average value \\
RDX 62, polyisobutylene 6, NC 30, DOZ 2 & 1100 & (904-1130), [1] \\
RDX 60, polyisobutylene 8, NC 30, DOZ 2 & 1080 & \\
RDX 58, polyisobutylene 10, NC 30, DOZ 2 & 1075 & \\
RDX 56, polyisobutylene 12, NC 30, DOZ 2 & 1050 & \\
\hline
\end{tabular}

From Table (5) and Figure (4), it is obvious that Combustion heat values increases by increasing RDX content. Also, the composition which contains RDX 56, 
polyisobutylene 12, NC 30, DOZ 2 produce residual carbon in bomb after combustion.

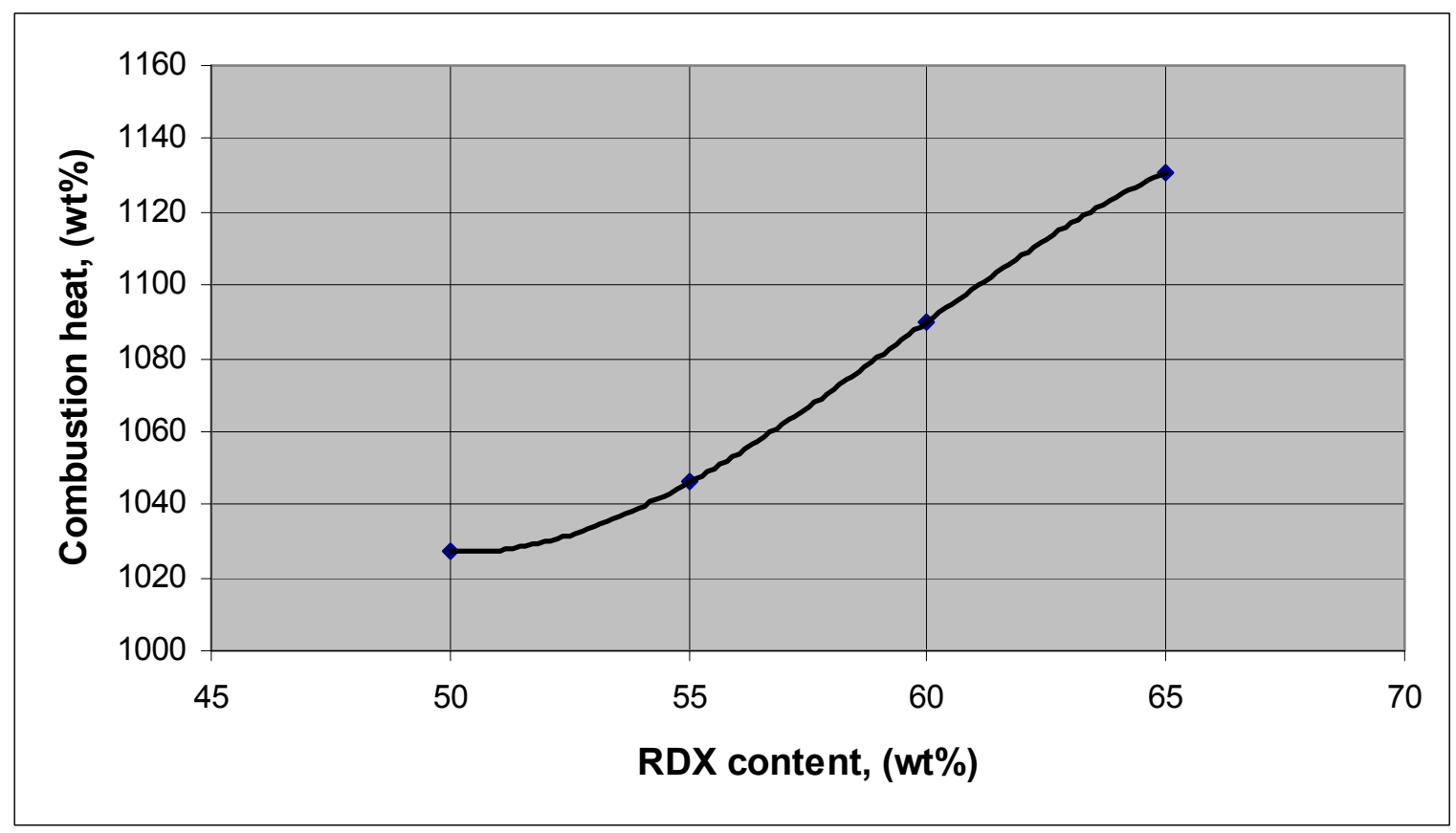

Fig.3. Variation of combustion heat with RDX content

In $100 \mathrm{cc}$ ballistic bomb the maximum pressure and relative vivacity are recorded in Table (5) and dynamic vivacity is recoded in Figure (4).

Table (5) Closed vessel data of S6 and triple base propellant

\begin{tabular}{|c|c|}
\hline Maximum pressure $\left(\mathbf{P}_{\max }\right)$ & $\begin{array}{c}\text { Triple base propellant = 1303 bar } \\
\mathbf{S 6}=1391 \text { bar }\end{array}$ \\
\hline Relative force & $106.778 \%$ \\
\hline Relative vivacity $(30-80)$ & $160.875 \%$ \\
\hline
\end{tabular}




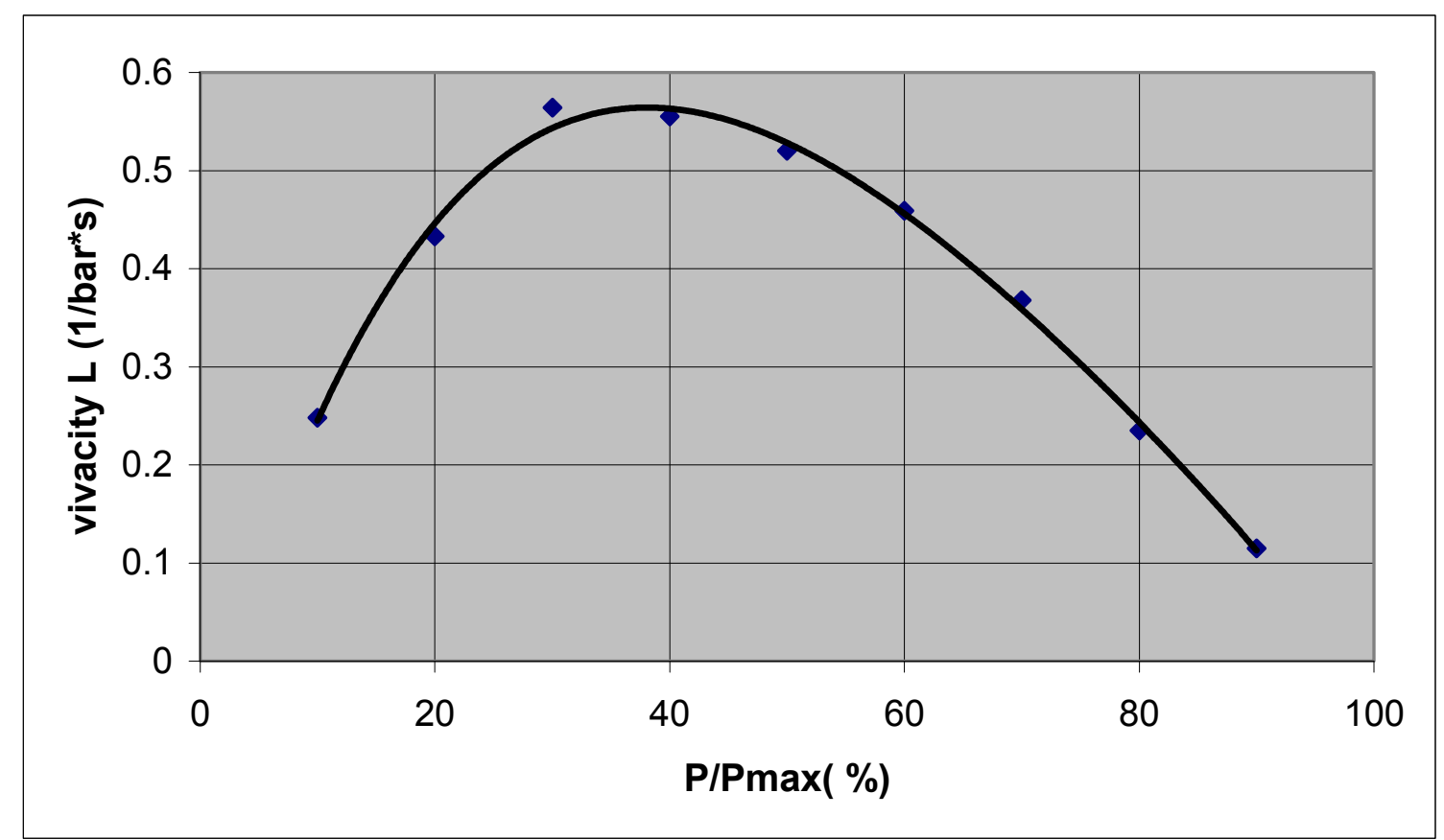

Fig.4. Dynamic vivacity of S6

From Table (5) and Figure (4), it is clear that S6 has approximately the same maximum pressure which will not affect on the barrel life time and the high relative vivacity indicates the high power of this modern propellant.

\subsection{Stability of The Prepared Formulations}

The results of Bergmann Junk test given in $\mathrm{ml}$ of nitrogen oxides per $5 \mathrm{gm}$ of powder are listed in Table (6) and illustrated in Figures (5).

Table 6. Data on thermal stability (Bergmann Junk Test at $120^{\circ} \mathrm{C}$ )

\begin{tabular}{|c|c|c|}
\hline Composition & $\begin{array}{l}\text { Experimental } \\
\text { values }\end{array}$ & $\begin{array}{l}\text { Literature } \\
\text { values }\end{array}$ \\
\hline RDX $60 \%$, NC $29 \%$, polyisobutylene $10 \%$, Cl $1 \%$ & 0.58 & \multirow{4}{*}{$\begin{array}{c}\text { Nitramine } \\
\text { gun } \\
\text { propellants } \\
\text { have } \\
\text { average } \\
\text { value } \\
(0.3-0.6), \\
{[12] .}\end{array}$} \\
\hline RDX $60 \%$, NC $29 \%$, polyisobutylene $10 \%$, DPA $1 \%$ & 0.40 & \\
\hline RDX $60 \%$, NC $28.5 \%$, polyisobutylene $10 \%, \mathrm{Cl} 1.5 \%$ & 0.42 & \\
\hline $\begin{array}{c}\text { RDX } 60 \%, \text { NC } 29 \% \text {, polyisobutylene } 10 \% \text {, Cl } 0.5 \%, \\
\text { DPA } 0.5 \%\end{array}$ & 0.46 & \\
\hline
\end{tabular}




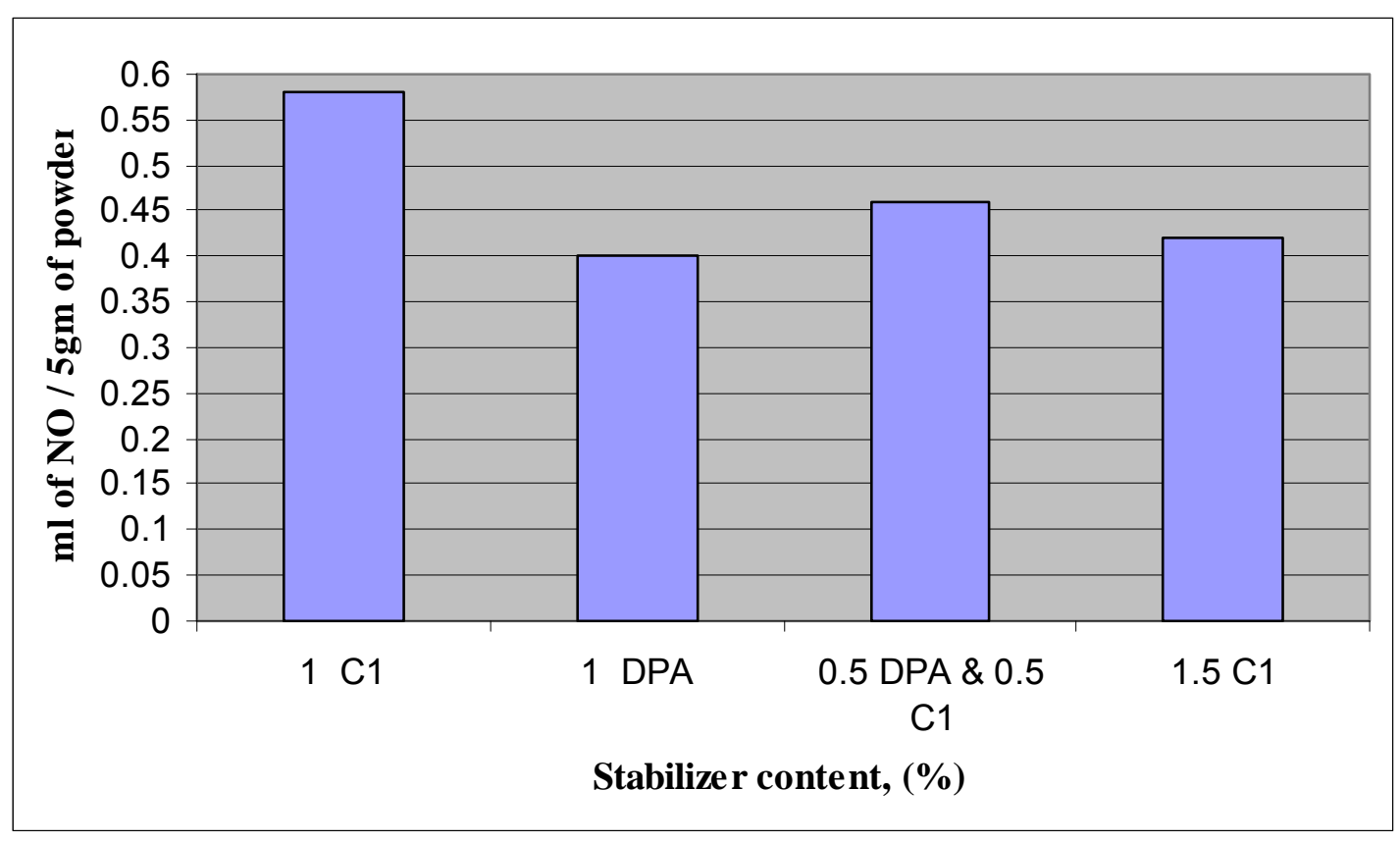

Fig.5. Variation of $\mathrm{ml}$ of $\mathrm{NO}$ oxides $/ 5 \mathrm{gm}$ of powder with stabilizer type

From Table (6) and Figure (5) it is obvious that quantity of nitrogen oxides decreases by increasing the content of the stabilizer, and DPA is the better stabilizer for modern gun propellants.

\section{CONCLUSIONS}

From this study it can be concluded that modern gun propellants with improved characteristics can be obtained from RDX, NC and polyisobutylene beads prepared using slurry technique.

We can say that the modern RDX based gun propellant possess several advantages:

1. Ease and simplicity of production, lower sensitivity to impact and friction, suitable heat sensitivity.

2. Improvement in performance (high energy content).

3. Increased safety and long term thermal stability.

Finally from the point of view of performance, sensitivity, stability and cost the recommended composition is RDX 58\%, polyisobutylene 10\%, NC 29\%, DOZ 2\%, DPA $1 \%$. 


\section{REFERENCES}

[1] Damse RS, Singh Haridwar, "Nitramine-based high energy propellant compositions for tank guns", Defence Science Journal Volume 50, (2000).

[2] M. A. Schroeder, R. A. Fifer, M. S. Miller, R. A. Pescerodriguez, C. J. S. Mcnesby, G. Singh, and J. M. Widder, "Condensed-Phase Processes during Combustion of Solid Gun Propellants. II. Nitramine Composite Propellants" U.S. Army Research Laboratory, USA, (2001). Fritz Schedlbauer, "LOVA Gun Propellants with GAP Binder", Propellants,

[3] Explosives, Pyrotechnics, Volume 17, (1992). Dietmar Mueller, "New Gun Propellant with CL-20" Propellants,

[4] Explosives, Pyrotechnics, Volume 24, (1999). D. Kasprzyk, D. Bell, R. Flesner and S. Larson; "Characterization of a slurry process used to make a PBX", Propellants, Explosives and

[5] Pyrotechnics, Volume 24, 333-338, (1999). Haaland Andrew C. (US), Braithwaite Paul C. (US) Hartwell James A (US),

[6] Lott Vald (US), Rose Michael T (US), "Process for the manufacture of high performance gun propellants", Patent NO.US6171530, (2001). R.R. Sanghavi, P.J. Kamale, M.A.R.

[7] IKA Maschinebou apparatus catalogue, Germany, (2000).

[8] Chilworth BAM friction apparatus catalogue, Germany, (1999).

[9] Deflagration test apparatus catalogue, UK, (2003).

[10] Perkin Elmer DTA-7 apparatus catalogue, GERMANY, (2002). Model 6200 Isoperibol PARR Bomb Calorimeter apparatus catalogue,

[11] USA, (2002). AB Bofors, Nobelkrut, "Analytical Methods for Powders and

[12] Explosives" Bofors, (1974). 